\title{
The Earliest Extant Example of Woodblock Printing: The Precept Certificate of the 29th Year of Kaiyuan (741 A.D.)
}

\author{
RONG Xinjiang
}

Peking University

Peking, China

DOI: $10.17816 / \mathrm{WMO} 77364$

Received 08.07.2021.

Abstract: In this paper, the present author focus on the three printed images of Buddha on the precept certificate from the Dayun Monastery of Dunhuang preserved in St. Petersburg (Дх.02881+Дх.02882). It is the earliest extant example of woodblock printing, with a definite date the 9th day of the 2nd month of the 29th year of Kaiyuan 開元 (A.D. 741), which has long been ignored by the specialists on the history of printing. The certificate was given the monk Daojian from the Great Anguo Monastery from the capital Chang'an, as the representative of the royal monastery. The precept certificate with printed Buddha images has great significance in the history of printing. Based on the facts that Sinicized monasteries in Central Asia and Japan should have the same institution as in Dunhuang and Chang'an, we can assume the certificate with the same woodblock printing was very likely to be spread to the Western Region (Central Asia) as well as to Japan.

Key words: woodblock printing, Buddhist certificate, Chang'an, Dunhuang, IOM RAS, MSS Дх.02881+Дх.02882.

Acknowledgements: I would like to take this opportunity to thank Professor Irina Popova for all kind of help when I research the manuscripts preserved in the Institute of Oriental Manuscripts, Russian Academy of Science, St. Petersburg. And I also thank Dr. Fu Ma for translating my paper into English.

For citation: Rong Xinjiang. "The Earliest Extant Example of Woodblock Printing: The Precept Certificate of the 29th Year of Kaiyuan (741 A.D.)". Pis'mennye pamiatniki Vostoka, 2021, vol. 46, no. 3 (iss. 46), pp. 118-126 (in English). DOI: 10.17816/WMO77364

About the author: RONG Xinjiang, Professor of History, FBA Department of History, Peking University (Beijing, China) (rxj@pku.edu.cn).

๑) Rong Xinjiang, 2021

Besides searching for related records in literatures, the most important approach to study the history of woodblock printing is the search of early block prints. The earliest extant dated example of woodblock printing is a Diamond Sutra 金剛經 dating back to the 9th year of Xiantong of the Tang dynasty, i.e., 868 A.D. Discovered in the Library cave of the Dunhuang grottoes, it is now housed in the British Library, coded S.P.002. It can be viewed as a com- 
plete block print book in the format of Chinese scroll, with the full length of $488 \mathrm{~cm}$ and printed drawings on the preface page (For the most in-depth study on this item, see Wood and Barnard 2010). Professor Deng Wenkuan has proposed to date the block print fragment of a calendar Дx.02880 to the 8th year of Taihe of the Tang Dynasty, i.e., 834 A.D., based on the record of the date and position of the Moon God, the reference of the 12 gods of jianchu, the map of 9 Palaces, the ganzhi of the shuo dates and the dates of $m i$ 蜜 (Deng Wenkuan 2000: 108-112. See also Su Ya 2000). If so, it is 34 years older than the above-mentioned Diamond Sutra. However, it is not noticed and accepted by the specialists on the history of printing, due to the lack of a definite dating and the relative small body of text with only 30 lines left. It should belong to the official block print of books, presumably brought from the heartland of Tang China or Sichuan.

As a stage earlier than the woodblock printing, the technology of seal-like stamps is not so advanced as the book printing, but it shares the same method. Therefore, the seal-like stamps are generally viewed as an early form of block print, different from seals, on-sand stamping 印沙 and etc. Some scholars have argued that the seal-like stamps emerged in the early Tang time, based on the record that the monk Xuanzang printed the image of Samantabhadra on huifeng paper 回鋒紙 in Sengyuan yilu 僧園逸錄 cited by Feng Zhi 馮䞇 of the later Tang time in his Yunxian sanlu 雲仙散錄. There are also similar records in other literatures, but none of them is doubtless and well accepted. As for the early examples of woodblock printing, the Dunhuang scroll BD14711 from the National Library of China, Chinese version of Samyuktābhi-dharma-hrdaya, bears the seal of the county of Yongxing 永興郡 at the end and on the back, along with 10 sets of Buddhist images printed on the back. Each set is centered with the combination of one Buddha and two accompanying Bodhisattvas, with 2 lines of Sanskrit to its left and right, 2 lines above and 4 lines underneath (The colored plate of a part of this scroll was for the first time published in Rare Book Section of National Library of China 2000: 6-7). Since the manuscript of Samyuktābhi-dharma-hrdaya on the recto can be dated to the period of the Northern and Southern Dynasties, judging from the calligraphy and the toponym 永興 (in use from the reign of the emperor Wu of the Northern Zhou till the 3rd year of Kaihuang of the emperor Wen of the Sui Dynasty, i.e., 583), some scholars argued to date these printed images to the same period. Considering the texts or images on the recto and verso sides of the Dunhuang manuscripts in many cases date to different periods, more and more scholars tend to date them to a later period, the Tang time (7-8 cc) [For the black and white plate of the whole scroll see National Library of China 2010: 159-169. For the commentary, see the appendix to the same book: 7-9]. In my opinion, the date of the printed images cannot be earlier than the middle Tang period. Next to the printed drawing on the preface of the Diamond Sutra of 868, the earliest printed Buddhist image with a definite date is the images of Mañjuśrī, Avalokiteśvar, Vaisramana and so forth created by Lei Yanmei, an artisan of the Guiyi Army in 947, i.e. S.P.8, S.P.9, P.4514 (Kikutake 1975: 12-15; Drège 1984: 56-57, pl. VII; Bai Huawen 1987: 45; Tsiang 2010: 214-218).

In this paper, I would like to focus on a manuscript with the seal-like stamps, which has long been ignored by the specialists on the history of printing. This is the precept certificate from the Dayun Monastery of Dunhuang preserved in St. Petersburg (Дх.02881+Дх.02882), which is the earliest extant example of woodblock printing, with a definite date the ninth day of the 2nd month of the 29th year of Kaiyuan 開元 (i.e., 741, Plate 1) [E cang 1998: color pl. 1; 109-110]. Joint by two fragments, the manuscript measures $28.4 \mathrm{~cm}$ by height and $64.4 \mathrm{~cm}$ by length. The whole Chinese text is as follows: 
(前缺)

\begin{tabular}{|c|c|}
\hline 1 & ]菩薩戒佛弟 [ \\
\hline 2 & 入烏波斯迦伍 \\
\hline 3 & ]不發出離之心，恐還: $\square \square[$ \\
\hline 4 & 閻浮 $\square$ （提） $\square \square \square \square \square$ (大) 唐國沙州燉煌縣大雲寺僧伽藍 $\square \square$ \\
\hline 5 & 京大安國寺法師講 《御注金岡經》、《法華》、《梵網經》, 清淨道場, \\
\hline 6 & 聽法二七 $\square$ (日)，然後韱悔四重、五逆、十惡、謗方等經一切諸 \\
\hline 7 & 罪, 今對十方諸佛、一切賢聖、天曹地府、善惡部官、閻羅 \\
\hline 8 & 大王、怨家債主、負財負命、 $\square \square$ 道眼證明，令得罪障消 \\
\hline 9 & 滅，授得金剛不壞 $\square \square \square \square$ 菩薩戒品具足，任編公驗，請 \\
\hline 10 & 乞大乘六念，謹牒。 \\
\hline 11 & 第一念佛 第二念法 第三念僧 第四念戒 第五念捨 \\
\hline 12 & 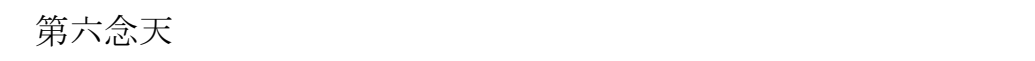 \\
\hline 13 & 佛像 開元廿九年二月九日授得菩薩戒 \\
\hline 14 & 傳菩薩戒和尚沙門釋道建（簽名） \\
\hline 15 & 俥作菩薩戒同學伴侶十方諸大菩薩 \\
\hline 16 & 佛像 證菩薩戒師十方諸佛 \\
\hline 17 & 教授阿闍梨當來 弥勒 菩薩 \\
\hline 18 & 達磨阿闍梨釋迦牟尼佛 \\
\hline 19 & 佛像：授菩薩 戒和尚 盧 舍 那佛 \\
\hline 20 & 今有眾多善男子、善女人等, 今於我所, 求受菩薩戒, 哳 \\
\hline 21 & 謂攝律儀戒，誓斷一切惡 ; \\
\hline 22 & 攝善法戒，誓求無上菩提 ; 饒益有情戒，誓度法戒（界）眾生； \\
\hline 23 & 是諸佛三聚淨戒。過去諸佛菩薩已受已學已成佛竟，未 \\
\hline 24 & 來菩薩當受當學當作，現今菩薩今 $\square \square \square$ 時學，即擬行 \\
\hline 25 & 當來作佛。如（汝）等善男子、善女人等能持不? \\
\hline 26 & 能持。於後如法脩行，莫放逸。 \\
\hline
\end{tabular}

This certificate was issued to a monk in the Dayun Monastery in Dunhuang by the master Daojian 道建(?), who gave Boddhisattva precepts there on the 9th day of the 2nd month of the 29th year of Kaiyuan during the reign of the emperor Xuanzong of the Tang dynasty. Three images of Buddha were printed between line 13 and 19 (Plate 2). The block is the standard image of the preaching of the Sakyamuni Buddha, illustrating him sitting cross-legged, with a high uṣnīṣa, a round face and a halo behind his head. He wears kasaya, with right hand in Abhaya-mudra and a halo behind his body. The picture fits the solemn scenario of the ritual of Boddhisattva precepts, with only floral decorations at the upper corners of the frame. The three images are identical, suggesting they were produced by the same woodblock. The irregular sequence of the three images is probably due to printing carelessly. 


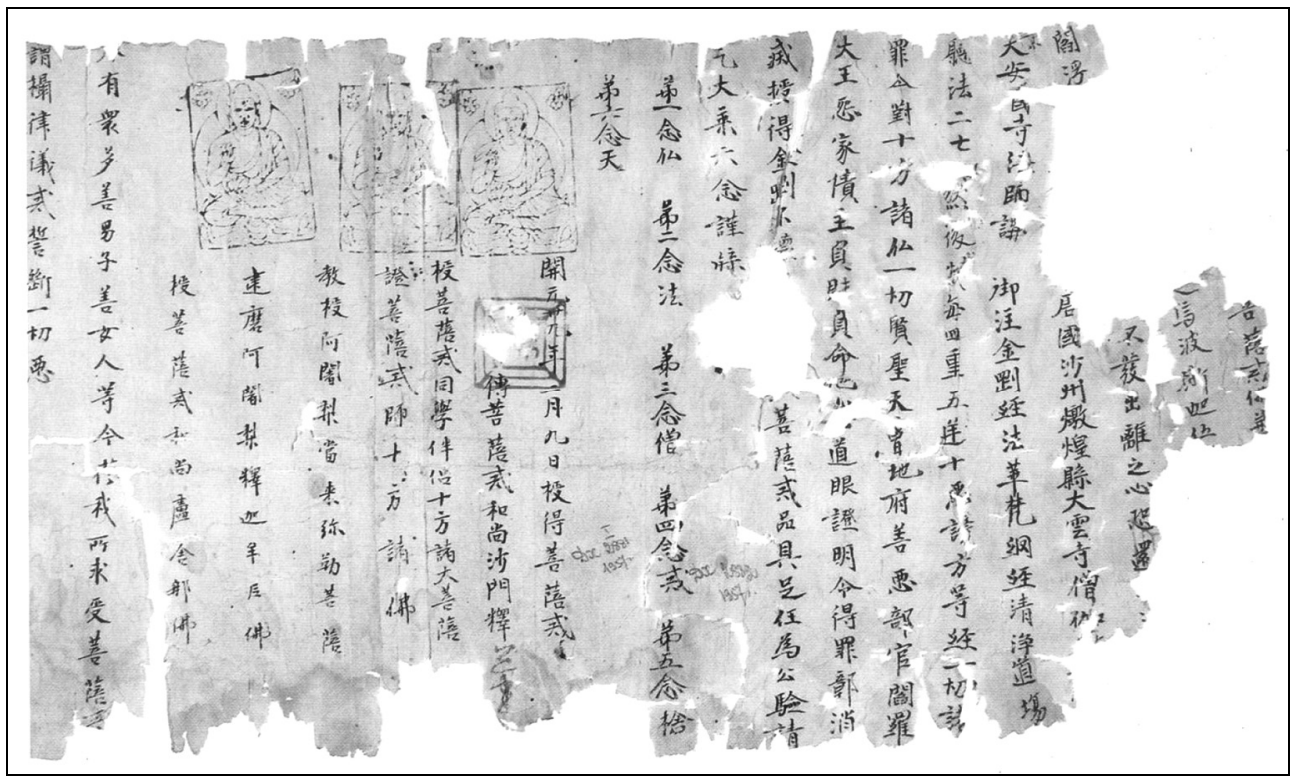

Plate I: Precept certificate from the Dayun Monastery of Dunhuang preserved in St. Petersburg (Дх.02881+Дх.02882).

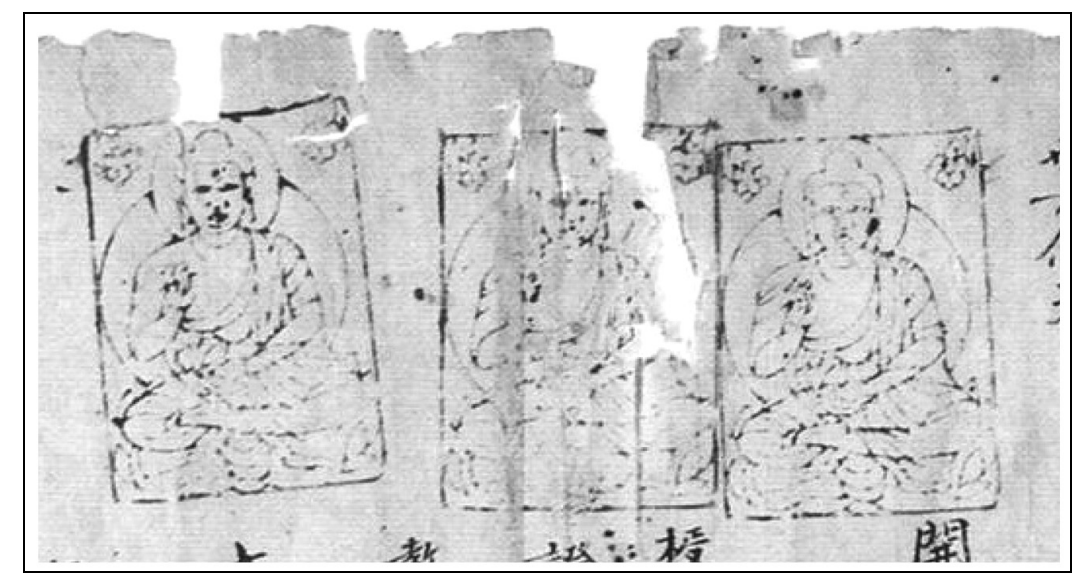

Plate II: Three images of Buddha in printed on the precept certificate from the Dayun Monastery of Dunhuang preserved in St. Petersburg (Дх.02881 + Дх.02882)

After the initiation of monkhood, one has to experience different periods of learning and thus different kinds of precepts, including Śrāmaṇera or Śrāmaṇerika, Bhikṣu or Bhikṣunī precepts, and Boddhisattva precepts (For the general description of Buddhist monks' precepts in China, see Qu Dacheng 2016: 28-73; For the monks' precepts in Dunhuang, see Hao Chunwen 1998; Zhanru 2003). The above-mentioned certificate is for Boddhisattva precepts. As I have already pointed out, this certificate (Дх.02881+Дх.02882) not only presents the so far earliest extant certificate for Boddhisattva precepts, but also reveals that it is the monk 
Daojian from the Great Anguo Monastery from the capital Chang'an, as the representative of the royal monastery, who gave the precepts to the monks in the Dayun Monastery in Dunhuang. As part of the ritual, Daojian also spent 14 days preaching three sutras to the monks in the Dayun Monastery, including the Diamond Sutra with the emperor's commentary 御注金 剛經, the Lotus Sutra, and the Brahmajāla Sutra. The Emperor Xuanzong accomplished his commentary to the Diamond Sutra in the 23rd year of Kaiyuan. In the 27 th year, the monks in Chang'an built the Prajna temple. On the 10th day of the 8th month in the same year, they gathered in the Great Anguo Monastery, preaching the Diamond Sutra with the emperor's commentary and the Humane King Sutra 仁王般若經. It is only two years later that Daojian brought the Diamond Sutra with the emperor's newly accomplished commentary to Dunhuang, preaching it to the local monks (For this part, see Rong Xinjiang 2007: 15-25; included in Rong Xinjiang 2009: 149-178). This reflects the central government's control on the local monks in the Tang times.

The certificate should be in the same format with those issued in Chang'an. The text could be written in Dunhuang, but the images of the Buddhas of ten directions could not be drawn in a short time. Therefore, it is more feasible to bring the woodblock of the images to Dunhuang and print them there. Otherwise, it is also possible that they brought the certificate with printed images from Chang'an and filled in the monks' name in Dunhuang. According to my examination of the manuscript in the Institute of Oriental Manuscripts, Russian Academy of Science, St. Petersburg, the paper has pretty fine and clean texture, resembling the paper made in Chang'an. A red square seal was stamped on the year when the ritual took place. It shows the image of a 3-storied altar, probably representing the altar for precepts. However, the characters in the middle are not legible due to the damage of the paper. Anyways, the purpose of this seal is clear: it is to prevent any change to the year.

The precept certificate with printed Buddha images has great significance in the history of printing. As we know, the power of Buddhism largely overwhelmed that of the Taoism in Tang times, even though the Tang court had tried to restrict it several times. Great numbers of monks and nuns undertook precepts every year, whilst the Tang court issued certificates to them as a method to control. In particular, the ministry of temples 祠部 replaced the Chongxuan department of the court of state ceremonials 䲨臚寺崇玄署 as the administrative department of the Buddhist societies in the 24th year of Kaiyuan, i.e., 736, as a strict measure taken by the Tang court. Therefore, we should relate the precept certificate in Dunhuang of 741 to this background. That the monk from the royal monastery came all the way to Dunhuang to take charge of the precept ritual of the local monks is very likely to be due to a new policy to strengthen the central control of the local Buddhist societies.

The monk Huichao 慧超 from Silla recorded the Buddhist monasteries in the Four Garrisons in Anxi Protectorate in his travel log during his visit in the 15th year of Kaiyuan, i.e., 727. I hereby cite Jan et al.'s English translation with necessary modification as follows (Jan et al. 1984: 57-58. See also Kuwayama 1992: 25-26):

From Congling I travelled another month and arrived at Kashgar. The foreigners call this place Kashgiri. The place is also guarded by Han troops. There are monasteries and monks. Hīnayāna Buddhism is practiced. People eat meat, onions, leeks, and such. The local inhabitants wear cotton clothes.

From Kashgar I travelled further east for one month and arrived at the country of Kucha. This is the headquarters of the great protectorate of Anxi, the place where Han troops are gathered. In Kucha there are many monasteries and monks. Hīnayāna 
Buddhism is practiced. The foods are meat, onions, leeks, and such. The Han monks practice Mahayana Buddhism.

Two thousand $l i$ from Anxi is the country of Khotan. There are also many Han troops stationed here. There are many monasteries and monks. Mahāyāna Buddhism is practiced. No monks eat meat.

From here eastward is all the territory of the Great Tang Empire. This is known to all. One can understand [the Situation] without further explanation.

I arrived at Anxi during the first ten-day period of the eleventh moon of the fifteenth year of the Kaiyuan era. At that time, the military governor was his excellency Chao.

There are two monasteries presided over by Han monks. They practice Mahāyāna Buddhism and eat no meat. The abbot of the Dayun Monastery is Xiuxing 秀行, who is well versed in discourse and speech. Previously, he was a monk of the Qibaotai Monastery in the capital. The Duty Distributor called Yichao 義超 understands the Vinaya Pitaka very well. Previously he was a monk of the Zhuangyan Monastery in the capital. The Chief Chair of the Dayun Monastery called Mingyun 明惲, who had a high moral character, originally came from the capital. These monks are good chiefs. They possess religious determination and perform religious worship with joy.

The abbot of the Longxing Monastery is called Fahai 法海. Though he is a Chinese born in Anxi, his scholarship and manners are not different from those of China.

There is a Chinese monastery called Longxing Monastery in Khotan. A Chinese monk called $<\ldots>$ is the abbot of the monastery and he is a good abbot. This monk is a native of Jizhou in Hebei.

There is also a Chinese monastery called the Dayun Monastery in Kashgar. A Chinese monk resides over the monastery, who is a native of Minzhou.

From Anxi I travelled further east for $<\ldots>$ and arrived at the country of Yanqi. The place is also guarded by Han troops. There is a king, and the inhabitants are Hu people. There are many monasteries and monks. Hīnayāna Buddhism is practiced.

There are four towns in the Anxi region, namely Anxi [Kucha], Khotan, Kashgar, and Yanqi $<\ldots>$

In the Anxi region, the Hīnayāna Buddhism was prevalent among the local Hu people in Kashgar, Kucha and Yanqi, whilst the Mahāyāna Buddhism in Khotan. On the other hand, the Mahāyāna Buddhism was practiced among the Han people in all the Four Garrisons in this region. Noteworthy is that the abbot of the Dayun Monastery in Kucha (Anxi) was a monk from the Qibaotai Monastery in Chang'an, the Duty Distributor a monk from the Zhuangyan Monastery in Chang'an, and the Chief Chair a monk from Chang'an as well. All the three leading monks of the official monastery in Kucha came from Chang'an. Moreover, I have once pointed out that Wudao [悟]道, a chief administrator of the whole Buddhist society in the Anxi region was also a monk from the Zhuangyan Monastery of Chang'an, based on a wall inscription taken from Kumtura Caves by the Otani expedition (Rong Xinjiang 2005: 130-137; included in Rong Xinjiang 2015: 153-160. For the English version, see: Rong Xinjiang 2010: 215-220. The name Wudao was reconstructed by Moriyasu 2007: 21; also Moriyasu 2015: 663). He specialized in Vinaya. We can therefore assume that these leading monks from Chang'an could have issued the same certificates as the one of 741 in Dunhuang, when they were in charge of the precept rituals of the local Han monks in the Anxi region. These certificates should have born similar printed images of the Buddha. Therefore, 
the woodblock printing images were very likely to be introduced to most of the Anxi region, as far as Suyab, which used to be one of the Four Garrisons.

The precept ritual practiced in the monasteries in Chang'an should have been introduced eastwards to Japan as well. Jianzhen 鑒真, the monk from Yangzhou who founded of the Japanese Vinaya School, had received the complete precepts in the Wenguo Monastery (former Shiji Monastery) in Chang'an in the 3rd month of the 2nd year of Jinglong (708) (See Mahito Genkai 2000: 34; See also Zanning 1987: 349). In the 21st year of Kaiyuan (733), Japan sent the 10th delegation of 594 people to the Tang court in four ships, including Rongrui and Puzhao, the monks from the Xingfu Monastery who were intended to receive Jianzhen (For the in-depth study on the Japanese delegation, see Ando 1960: 59-86). Through several rounds of troubles, Jianzhen finally arrived in Japan in the 14th year of Tianbao (754), introducing the Vinaya School there. We can thus assume that the ritual as well as the certificate given by Jianzhen there should be the same as that in Chang'an. The printed images on the certificate were very likely introduced to Japan in such background.

Scholars tend to stress the significant role of the Buddhist Tantric School in the invention and development of printings, based on the emergence of printed Dharani during the period of High and Middle Tang. I do not intend to join in the discussion of the early history of printing in this paper. My primary purpose is to draw attention to the precept certificate of 741 in the St. Petersburg collection, which has long been ignored by the specialists in the history of printing, and to argue that the printed images of Buddha on it should be the earliest extant dated example of woodblock printing in the world. Further, I suppose, the development and spread of early woodblock printing was very likely to be prompted by the huge need for this kind of precept certificate with printed image. Based on the facts that Sinicized monasteries in Anxi and Japan should have the same institution as in Dunhuang and Chang'an, we can assume the precept ritual and certificate should be the same in these regions. Woodblock printing was very likely to spread to the Western Region (Central Asia) as well as to Japan, along with the spread of the Sinicized precept activities.

\section{Reference}

Ando Kousei 安藤更生. Ganjin daiwajoden no kenkyu 鑒真大和上傳之研究. Tokyo: Heibonsha, 1960 (in Japanese).

Bai Huawen 白化文. “Survey of the Woodcut Prints in the Dunhuang Chinese Materials”敦煌漢文遺 書中雕版印刷資料綜述. Daxue Tushuguan tongxun 大學圖書館通訊, 1987, no. 3, pp. 44-52 (in Chinese).

Deng Wenkuan 鄧文寬. “Three Fragments of Calendar from Dunhuang” 敦煌三篇具注曆日佚文校 考. Dunhuang yanjiu 敦煌研究, 2000, no. 3, pp. 108-112 (in Chinese).

Drège, J.-P. "Éléments méthodologiques pour l'étude des documents de Dunhuang”. Les peintures murales et les manuscrits de Dunhuang ed. M. Soymié, Paris, 1984, pp. 53-59 (in French).

E cang Dunhuang wenxian (Dunhuang Manuscripts kept in Russia) 俄藏敦煌文獻, vol. 10. Shanghai: Shanghai guji chubanshe, 1998 (in Chinese).

Hao Chunwen 郝春文. Tang houqi Wudai Songchu Dunhuang sengni de shehui shenghuo 唐後期五代 宋初敦煌僧尼的社會生活. Beijing: Zhongguo shehuikexue chubanshe, 1998 (in Chinese).

Jan, Yun-hua et al. The Hye Ch'o Diary: Memoir of the Pilgrimage to the Five Regions of India 慧超 往五天䇥國傳. Berkeley: Asian Humanities Press, 1984 (in English). 
Kikutake Jun'ichi 菊竹淳一. “Buddhist Woodcut Prints from Dunhuang”敦煌の佛教版畫. Ars Buddhica 佛教藝術, 1975, no. 101, pp. 3-35 (in Japanese).

Kuwayama Shoshin 桑山正進 (ed.). Huichao's Wang Wu-Tianzhuguo zhuan Record of Travels in Five Indic Regions. Tanslation and Commentary. 慧超往五天竺國傳研究. Kyoto: Institute for Research in Humanities, Kyoto University, 1992 (in Japanese).

Mahito Genkai 真人元開. To daiwajo toseiden / Tang daheshang dongzheng zhuan 唐大和上東征傳, with commentaries by Wang Xiangrong 汪向榮. Beijing: Zhonghua shuju, 2000 (in Chinese).

Moriyasu Takao 森安孝夫. “Chronology of West Uighur Buddhism: Re-examination of the Dating of the Wall-paintings in Grünwedel's Cave No. 8 (New: No. 18). Bezeklik”西ウイグル仏教のクロノ ロジー——゙ゼクリクのグリユンヴェーデル編號第 8 窟 (新編號第 18 窟) の壁畫年代再考. Bukkyō-gaku kenkyū 佛教學研究, 2007, vol. 62/63, pp. 1-45 (in Japanese).

Moriyasu Takao. Tōzai Uiguru to Cyūō Yūrasia (East-and West-Uighurs in the Central Eurasia) 東西 ウイグルと中央ユーラシア. Nagoya: Nagoya University Press, 2015 (In Japanese).

National Library of China 中國國家圖書館 (ed.). Guojia Tushuguan cang Dunhuang yishu (Dunhuang Manuscripts Preserved in the National Library) 國家圖書館藏敦煌遺書, vol. 132. Beijing: Press of Beijing Library, 2010 (in Chinese).

Qu Dacheng 屈大成. Zhongguo Fojiao lvzhi yaoyi 中國佛教律制要義, Tainan: Heyu chubanshe, 2016 (in Chinese).

Rare Book Section of National Library of China 中國國家圖書館善本特藏部 et al. (eds.). Zhongguo Guojia Tushuguan cang Dunhuang yishu jingpinxuan (Masterpieces of Dunhuang Manuscripts Preserved in the National Library of China) 中國國家圖書館藏敦煌遺書精品選. Beijing: No Publisher, 2000 (in Chinese).

Rong Xinjiang 榮新江. “The Network of Chinese Buddhist Monasteries in the Western Regions under Tang Control” 唐代西域的漢化佛寺系統. Xinjiang Kucha Society 新疆龜茲學會 (ed.). In: Qiuci wenhua yanjiu 龜茲文化研究, vol. 1, Hong Kong: Tianma chuban youxian gongsi, 2005, pp. 130-137 (in Chinese).

Rong Xinjiang. "Chang'an and Dunhuang in the High Tang: A Study on the Certificate Dated to 741 A.D. in the Russian Collections” 盛唐長安與敦煌——從俄藏〈開元廿九年（741）授戒牒〉談 起. Zhejiang daxue xuebao 浙江大學學報, 2007, vol. 37, no. 3, pp. 15-25 (in Chinese).

Rong Xinjiang. Sui Tang Chang'an: Xingbie, jiyi jiqita 隋唐長安: 性別、記憶及其他. Hong Kong: Joint Publishing (H.K.) Co., Ltd., 2009 (in Chinese).

Rong Xinjiang. "The Network of Chinese Buddhist Monasteries in the Western Regions under Tang Control". "The Way of Buddha" 2003: The 100th Anniversary of the Otani Mission and the 50th of the Research Society for Central Asian Cultures. (Cultures of the Silk Road and Modern Science, Vol. 1.), ed. Irisawa Takashi 入澤崇, Osaka: Toho Shuppan, 2010, pp. 215-220 (in English).

Rong Xinjiang. Sichouzhilu yu dongxi wenhua jiaoliu 絲綢之路與東西文化交流, Beijing: Peking University Press, 2015 (in Chinese).

Su Ya 蘇雅. “The Earliest Extant Printed Matter found in China: Calendar in A.D. 834” 我國發現的現 存最早雕版印刷品——唐大和八年甲寅歲（834）具注曆日. In: Newsletter of Cultural Relics in China 中國文物報, Feb. 2, 2000, p. 3 (in Chinese).

Tsiang, Katherine R. "Buddhist Printed Images and Texts of the Eighth-Tenth Centuries: Typologies of Replication and Representation". In: Esoteric Buddhism at Dunhuang. Rites and teachings for this life and beyond, eds. Matthew T. Kapstein and Sam van Schaik. Leiden: Brill, 2010, pp. 201-252 (in English).

Wood, F. \& M. Barnard. The Diamond Sutra: The Story of the World's Earliest Dated Printed Book. London: The British Library, 2010 (in English).

Zanning 贊寧. Song Gaoseng zhuan 宋高僧傳, Beijing: Zhonghua shuju, 1987 (in Chinese).

Zhanru 湛如. Dunhuang Fojiao lvyi zhidu yanjiu 敦煌佛教律儀制度研究, Beijing: Zhonghua shuju, 2003 (in Chinese). 


\section{Самый ранний экземпляр ксилографа: сертификат наставника от 29-го года Кайюань (741 г.)}

\section{ЖУН Синьцзян}

Пекинский университет

Пекин, Китай

Статья поступила в редакцию 08.07.2021.

Аннотация: Статья посвящена трем печатным образам Будды на сертификате наставника из монастыря Даюнь в Дуньхуане, который хранится в ИВР РАН (Дх.02881+Дх.02882). Это самый ранний экземпляр ксилографической печати, имеющий точную дату — 9-й день 2-го месяца 29-го года Кайюань (741 г.), который до сих пор не рассматривался специалистами по истории книгопечатания. Сертификат был выдан монаху Даоцзянь из Монастыря Большой Аньго в столице Чанъань, подтверждая его принадлежность к императорскому монастырю. Сертификат наставника с печатными изображениями Будды имеет большое значение для истории книгопечатания. Принимая во внимание, что китаизированные монастыри в Центральной Азии и Японии имели такие же административные структуры как в Дуньхуане и Чанъани, следует предположить, что сертификаты с подобными печатными изображениями были распространены и в Западном регионе (Центральной Азии), и в Японии.

Ключевые слова: ксилография, буддийский сертификат, Чанъань, Дуньхуан, ИВР PAH, MSS Дх.02881+Дх.02882.

Благодарность: Я искренне благодарю проф. Ирину Ф. Попову за помощь во время моей работы с рукописями в Институте восточных рукописей РАН, Санкт-Петербург. Я также признательна д-ру Фу Ма за перевод моей статьи на английский язык.

Для цитирования: Жун Синьцзян. Самый ранний экземпляр ксилографа: сертификат наставника от 29-го года Кайюань (741 г.) // Письменные памятники Востока. 2021. Т. 18. № 3 (вып. 46). C. 118-126 (на англ. яз.). DOI: 10.17816/WMO77364

Об авторе: ЖУН Синьцзян, профессор исторического факультета Пекинского университета. (Пекин, Китай) (rxj@pku.edu.cn). 